\title{
In vitro Assessment of Anti-aging Properties of Syzygium cumini (l.) Leaves Extract
}

\author{
Rebeca M Lima1 ${ }^{1}$, Hudson C Polonini' ${ }^{1}$, Marcos AF Brandão ${ }^{1}$, Francisco J Raposo ${ }^{1}$, Rafael C Dutra*2 and Nádia RB \\ Raposo $^{1}$
}

${ }^{1}$ Research and Innovation in Health Sciences (NUPICS), Brazil

${ }^{2}$ Department of Health Sciences, Brazil

Received: 阱January 19, 2019; Published: 阱January 28, 2019

*Corresponding author: Rafael C Dutra, Laboratório de Autoimunidade e Imunofarmacologia (LAIF), Departamento de Ciências da Saúde, Centro de Ciências, Tecnologias e Saúde, Campus Araranguá. Rodovia Governador Jorge Lacerda, no 3201 - Km 35.4, Bairro Jardim das Avenidas, Universidade Federal de Santa Catarina, CEP 88906-072, Araranguá, SC, Brazil

\begin{abstract}
Syzygium cumini (L.) Skeels (Myrtaceae) is known to contain phenolic compounds and antioxidant activity of its fruit, bark, and seeds have been investigated. However, there is limited information available regarding biological activities of its leaves. This study investigated phenolic contents and in vitro anti-aging potential effect and toxicity of ethanol extract from the leaves of S. cumini Photoprotection activity was investigated using diffuse transmittance. The extract was tested for antioxidant and tyrosinase inhibition activities using colorimetric methods. Cytotoxicity effects were evaluated on viability human HaCaT keratinocyte cell line through 3-(4,5-dimethylthiazol-2-yl)-2,5-diphenyltetrazolium bromide (MTT) assay, and in vivo toxicity effect was evaluated in the brine shrimp lethality test. Herein, the ethanol extract of $S$. cumini leaves showed a significant phenolic and flavonoid contents of $19.69 \pm 0.87$ and $1.21 \pm 0.081 \mathrm{mg} / 100 \mathrm{mg}$, respectively. Moreover, the extract of $S$. cumini showed elevated DPPH scavenging activity, with IC50 values of $9.85 \pm 0.51 \mu \mathrm{g} / \mathrm{ml}$, photoprotective actions (SPF $=13 \pm 2.9$, UVA protection factor $=5 \pm 0.2$ and UVA/UVB Ratio $=0.55)$ and tyrosinase inhibition activity $(I A 50=219.52 \mu \mathrm{g} / \mathrm{ml})$. The extract of S. cumini showed low and moderate cytotoxicity on human keratinocytes and brine shrimp assay. Altogether, our data support the effectiveness of $S$. cumini as the potential component of topical cosmeceutical for its anti-aging properties and represents significant implications for biomedical research.
\end{abstract}

Keywords: Syzygium Cumini; Sunscreen Agents; Sun Protection Factor; Antioxidant Activity

\section{Introduction}

Syzygium cumini (L.) Skeels (Myrtaceae) is a plant originating from the tropics, in particular, from India, Thailand, Philippines and Madagascar, and it is also found in several states of the southeast, northeast and north regions of Brazil [1,2]. S. cumini is known for its hepatoprotective, anti-allergic, hypoglycaemic, hypolipidaemic, anti-fungal, antiviral, anti-inflammatory and antioxidant properties, which are attributed to the presence of bioactive compounds in different parts of the plant [3-9]. The chemical composition of $S$. cumini leaves revealed the presence of phenolic compounds such as gallic acid, betulinic acid, myricetin, ellagic acid, chlorogenic acid, and quercetin, besides other components such as canferol, methyl gallate and nilocitin [10-16]. Phenolic compounds have received much attention lately, as they are natural inhibitors of oxidation and a source of broad-spectrum natural sunscreens [17-22]. It has been reported that there are plenty of opportunities in the market for these natural ingredients because they have a positive reputation to be readily accepted [23]. Furthermore, pieces of evidence show that topically applied antioxidants can be used for protection against sun damage [24,25], healing of wounds [23], as well as can act as antiinflammatory agents [26,27]. To achieve a safe treatment strategy using natural products, brine shrimp lethality assay can be used in toxicology tests, which screens a large number of extracts for drug discovery in medicinal plants [28-31], and marine products [32]. In vitro toxicology analysis using human keratinocyte cells (HaCaT cell line) has also been used as an important alternative for early toxicity assessment. Moreover, keratinocytes are the most common cell type in the epidermis (about 90\%), and thus they are used frequently as an epidermal model system [33,34]. Keeping the above data in mind, the purpose of the present study was to investigate the anti-aging potential and toxicity of ethanol extract from leaves of S. cumini, as well as its total phenolic and flavonoid contents. 


\section{Materials and Methods}

\section{Plant Material}

The leaves of S. cumini were collected in April 2016 from the Federal University of Juiz de Fora (UFJF) - Juiz de Fora, Minas Gerais, Brazil, and identified by Research Fátima Regina Gonçalves Salimena, UFJF, Brazil - voucher specimen (CESJ 35342) from Leopoldo Krieger Herbarium of UFJF. The collected leaves were dried at $40^{\circ} \mathrm{C}$ in a kiln and then reduced to powder using a knife mill (TA-2; Metvisa, Brazil).

\section{Preparation of the Extract}

Ethanol extract was obtained from $10 \mathrm{~g}$ of dried leaves were weighed and macerated in ethanol for $72 \mathrm{~h}$ at room temperature. The residue was removed by filtration, and the extract was evaporated to dryness at a lower temperature $\left(<40^{\circ} \mathrm{C}\right)$ under reduced pressure in a rotary evaporator (R-114; Buchi, Switzerland), obtained yield of $9.4 \% \mathrm{w} / \mathrm{w}$. The material was stored protected from light in airtight containers with the cap at $-20^{\circ} \mathrm{C}$ to use.

\section{Phytochemical Assay}

Secondary metabolites (flavonoids, tannins, coumarins, heterosides, saponins, alkaloids and anthraquinones) were investigated in the leaves of $S$. cumini through reactions of functional groups of the molecule according to Matos [35].

\section{Total Phenolic Content}

The total phenolic content was determined by the spectrophotometric method, as described previously [36], with few modifications, using Folin-Ciocalteu reagent. Briefly, we added $50 \mu \mathrm{l}$ of extract dissolved in ethanol solution $(10 \mathrm{mg} / \mathrm{ml})$, $250 \mu \mathrm{l}$ of Folin-Ciocalteu reagent, $500 \mu \mathrm{l}$ of $20 \%$ sodium carbonate and $4.2 \mathrm{ml}$ of distilled water. This reaction proceeded at room temperature, in the dark, for $30 \mathrm{~min}$. Then, the absorbance was read on a spectrophotometer (Multiskan GO, Thermo Scientific, USA) at $\lambda=765 \mathrm{~nm}$. Gallic acid (Sigma-Aldrich, USA) was used a standard, and its ethanolic solutions $(25-700 \mu \mathrm{g} / \mathrm{ml})$ were used to construct a standard curve for determining the extract's phenolic content. Tests were performed in triplicate, and the results were expressed in milligram of gallic acid equivalents per $100 \mathrm{mg}$ dry extract. The total phenolic content of the extract was determined by extrapolation of the analytical curve constructed from the gallic acid standard.

\section{Total Flavonoid Content}

Determination of flavonoids was performed according to Quettier-Deleu [37], with modifications, through reaction with aluminum chloride, resulting in a yellow complex, whose absorbance can be measured in a spectrophotometer. The medium contents of flavonoids were rutin (Sigma-Aldrich, USA) equivalents, which were used as a standard for the construction of the calibration curve $(2-30 \mu \mathrm{g} / \mathrm{ml})$. To quantify the flavonoid content, $2.5 \mathrm{ml}$ of extract was semi-purified in ethanol solution $(10 \mathrm{mg} / \mathrm{ml})$ by 4 adding aliquots of $1 \mathrm{ml}$ of chloroform and $1.5 \mathrm{ml}$ of distilled water. The resulting solutions were mixed and centrifuged for 3 $\min$ at $2,465 \mathrm{x} g$ at room temperature. The aqueous phase $(20 \mu \mathrm{l})$ was mixed with distilled water $(99 \mu \mathrm{l}), 8 \%$ aluminum chloride $(2 \mu \mathrm{l})$, pyridine methanol solution $(100 \mu \mathrm{l})$ and glacial acetic acid $(6 \mu \mathrm{l})$. Following incubation for $15 \mathrm{~min}$ (room temperature), the absorbance was measured in a spectrophotometer $(\lambda=405 \mathrm{~nm})$. Tests were carried out in triplicate, and the results were expressed as milligram rutin equivalents per $100 \mathrm{mg}$ dry extract.

\section{Antioxidant Activity}

The scavenging activity of $S$. cumini leaves was measured according to the 1,1-diphenyl-2-picrylhydrazyl free radical (DPPH) method, as described previously by Sreejayan and Rao [38], with minor modifications. Briefly, the sample $(50 \mu \mathrm{l})$ at different extract concentrations $(0.97-250 \mu \mathrm{g} / \mathrm{ml})$ was added to each well of a 96well microplate and mixed with $150 \mu \mathrm{l}$ of $50 \mu \mathrm{M}$ DPPH in ethanol solution. The reaction mixture was then kept for $30 \mathrm{~min}$ in the dark at room temperature. Then, the absorbance was measured in a spectrophotometer at $\lambda=510 \mathrm{~nm}$ against the negative control (ethanol). Ascorbic acid and Resveratrol (Sigma-Aldrich, USA) was used as positive controls at the same concentrations. Inhibition of DPPH radical was calculated using the following equation: IC50 $(\%)=100 \times(\mathrm{A} 0-\mathrm{As}) / \mathrm{A} 0$, where $\mathrm{A} 0$ and As are the values for the absorbance of the negative control and the absorbance of the sample, respectively. The IC50 value was calculated from the straight-line equation of the linear dispersion graph and represents the extract concentration that inhibits $50 \%$ of DPPH radical. All tests were performed in triplicate.

\section{Photoprotection Assay}

The photoprotection capacity of $S$. cumini leaves was measured according to Polonini and colleagues [39], conducted in UV-2000S Ultraviolet Transmittance Analyzer (Labsphere, USA) equipped with two photodiode array spectrographs and integrating sphere. Xenon flash lamp, that emits a continuous spectrum of radiation with no peaks, supplies energy in the spectral range $(290-450 \mathrm{~nm})$ with an increment step of $1 \mathrm{~nm}$ and has a low irradiance, such that photostability of the product is not unduly challenged. Moreover, analyzes were performed on square-shaped (50 $\times 50 \mathrm{~mm})$ polymethylmethacrylate (PMMA) Helioplate ${ }^{\text {TM }}$ HD6 (HelioScreen, France) plates with roughened surface one side $(\mathrm{Sa} \approx 6 \mu \mathrm{m})$ were used as the substrate for the determination of sunscreen protection factor (SPF) by diffuse transmittance spectrophotometry. Electronic analytical balance (AY - 220, Shimadzu, Japan) was used in the compounding of the sunscreen products. The samples were accurately weighed on the PMMA plate surface to satisfy the application rate of $1.3 \mathrm{mg} / \mathrm{cm} 2$ in each plate.

Then, the products were spread over the whole surface using a fingertip covered with a vinyl glove and pre-saturated with the product. For each product, three plates were prepared, which were kept protected from light exposure in a dark chamber at room temperature $\left(\approx 20^{\circ} \mathrm{C}\right)$ for $15 \mathrm{~min}$. Following, the transmission of UV radiation through the sample was measured from 290 to $450 \mathrm{~nm}$ at $1 \mathrm{~nm}$ intervals on nine different sites of each plate. The blank was prepared using HD6 plates covered with $15 \mu$ of glycerine because 
of its non-fluorescence and UV transparency. Then, UVB protection efficacy as SPF; and UVA protection efficacy a UVA/UVB Ratio and Critical Wavelength were calculated, as equations described previously [40]. The validity of experiments were obtained using the Cosmetics Europe Reference Sunscreen S2 (determined $\mathrm{SPF}=18 \pm 1.5, \mathrm{UVAPF}=12 \pm 1.1, \lambda$ critical $=381 \mathrm{~nm}$, and UVA/UVB ratio $=0.88$ ). During UVAPF analysis, two UV spectrums were obtained, after exposing the plates to calculated UV dose. Before, UVAPF, UVA/UVB ratio and SPF label as the critical wavelength were calculated. Data are expressed as mean of 27 measures for the lotion containing $15 \%$ of $S$. cumini extract.

\section{Tyrosinase Inhibition}

Tyrosinase inhibition qualitative enzymatic reaction screening was performed according to the protocol described previously [41], with some modifications. S. cumini extract was diluted in the microplate wells to concentrations of $100,80,40,20$ and $10 \mu \mathrm{g} /$ $\mathrm{ml}$ with $2.5 \%$ DMSO, and the kojic acid (positive control, SigmaAldrich, USA) was diluted to concentrations of 10, 5, 2.5, 1.25 and $0.625 \mu \mathrm{g} / \mathrm{ml}$. Then, aliquots of $10 \mu \mathrm{l}$ of a solution composed of 125 $\mathrm{U} / \mathrm{ml}$ of mushroom tyrosinase (Sigma-Aldrich, USA) were added in 96-well microplates, $70 \mu \mathrm{l}$ of phosphate buffer solution $(\mathrm{pH}$ 6.8 ) and $60 \mu \mathrm{l}$ of $S$. cumini extract was also added. For the negative control, $60 \mu$ l of $2.5 \%$ DMSO was added. The absorbances of the microplate wells were read on a spectrophotometer at $\lambda=510$ $\mathrm{nm}$ (T0). Then, the microplates were incubated at $30 \pm 1{ }^{\circ} \mathrm{C}$ for 60 $\mathrm{min}$, and the absorbances were measured again (T1). An additional incubation for $60 \mathrm{~min}$ at $30 \pm 1{ }^{\circ} \mathrm{C}$ was carried out, after which a new spectrophotometric reading was taken (T2). The inhibitory percentage at the two time points (T1 and T2) was obtained according to the equation: $\mathrm{IA}(\%)=100 \times(\mathrm{C}-\mathrm{S}) / \mathrm{C}$, where IA $(\%)$ is inhibitory activity; $\mathrm{C}=$ negative control absorbance; $\mathrm{S}=$ sample or positive control absorbance (absorbance at time T1 or T2 minus the absorbance at time T0). The analytical curve was plotted between tyrosinase inhibition activity percentages at each time point and the concentrations of the extract/positive control. Using the equation of the line, the inhibitory activity at 50\% (IA50, in $\mu \mathrm{g}$ / $\mathrm{ml}$ ) was calculated.

\section{Cell Viability Assay}

Human keratinocyte cells (HaCaT cell line) were cultured as adherent monolayers in Dubelcco's Modified Eagle`s Medium (DMEM) supplemented with $10 \%$ heat-inactivated FBS, $100 \mathrm{U} / \mathrm{ml}$ penicillin, $100 \mu \mathrm{g} / \mathrm{ml}$ streptomycin and $10 \mathrm{mM}$ HEPES and maintained at 37 ${ }^{\circ} \mathrm{C}$ in a $5 \% \mathrm{CO}_{2}$ humidified atmosphere at $\mathrm{pH}=7.4$. The cell viability study was performed using the 3-(4,5-dimethylthiazol-2-yl)-2,5 diphenyltetrazolium bromide (MTT) assay [42]. Briefly, HaCaT cells was seeded in 96-well plates at a density of $5 \times 10^{4}$ cells $/ \mathrm{ml}$ in $100 \mu \mathrm{l}$ of medium per well. After $24 \mathrm{~h}$ of incubation, the culture medium was replaced by fresh medium with the treatments. Sextuplicate wells were treated with $S$. cumini extract at concentrations ranging from $500-7.81 \mu \mathrm{g} / \mathrm{ml}$. The plates were incubated at $37{ }^{\circ} \mathrm{C}$ in $5 \% \mathrm{CO}_{2}$. A control experiment was performed under the same conditions, but without cell treatment. After $24 \mathrm{~h}$, the medium was removed and $200 \mu \mathrm{l}$ of DMEM with $50 \mu \mathrm{l}$ of MTT ( $5 \mathrm{mg} / \mathrm{ml}$ ) dye solution was added, followed incubation for $3 \mathrm{~h}$ at $37^{\circ} \mathrm{C}$. The precipitated formazan was then dissolved in DMSO, and the absorbance was measured at $\lambda=570 \mathrm{~nm}$ using a microplate reader. Cell viability (\%) was expressed as a percentage of the absorbance of non-treated control cells. IC50 value is the concentration of sample required to inhibit $50 \%$ of the cell proliferation and was calculated plotting the percentage survival vs. the concentrations, using GraphPad Prism 6 software (GraphPad Software Inc., San Diego, CA, USA).

\section{Brine Shrimp Lethality Assay}

The brine shrimp lethality assay was performed according to the protocol described [43], with some modifications. Brine shrimp cysts were obtained from Maramar Aquacultura (Cabo Frio, Rio de Janeiro, Brazil) and incubated in artificial seawater and exposed to a 60-W lamp at pH 8-9. After $48 \mathrm{~h}$ of incubation at room temperature $\left(22-29^{\circ} \mathrm{C}\right)$, the active nauplii free from eggshells (10 units) was collected and added to each set of wells containing crude ethanol extract dissolved in 2.5\% DMSO and made up to $5 \mathrm{ml}$ total volume using artificial salt water. The extracts were tested in triplicate at $1000-10 \mu \mathrm{g} / \mathrm{ml}$. In addition, thymol and 2.5\% DMSO were used as positive and negative controls, respectively (and artificial seawater a negative control). After $24 \mathrm{~h}$, the number of survivors was counted using a binocular microscope, and the percentage of deaths was calculated. The lethal concentration $50 \%$ (LC50 value) and the standard error were calculated by Probit analysis [44].

\section{Statistical Analysis}

The results were calculated as a mean \pm standard deviation (SD). All experiments were analyzed by Analysis of Variance (ANOVA), and Tukey's test was used as post hoc multiple comparisons between treatment group and control. $\mathrm{P}<0.05,0.01$ and 0.001 were considered significant. The statistical analyses were performed using GraphPad Prism 6 software (GraphPad Software Inc., San Diego, CA, USA).

\section{Results and Discussion}

Phytochemical screening of leaves of $S$. cumini showed the presence of flavonoids, tannins, triterpene heterosides, and saponins, which were similarly reported by Ayyanar [45]. Tannins and flavonoids are secondary metabolites classified as polyphenols, which are compounds that have broad-spectrum biological activities, including the ability to sequester free radicals [46]. Recently, there has been increasing interest in the natural antioxidants contained in the medicinal plants, which are candidates to prevent oxidative damage, including skin disorders $[47,48]$. The antioxidant and free-radical-scavenging property of flavonoids can be attributed to the high mobility of the electrons in the benzenoid nucleus and are well known for enhancing the wound healing process [49]. These properties can be easily applied to skin-related ailments as reducing the production of free radicals, prevent damaging the structure and functions of skin cells. Next, we investigated whether the treatment with ethanol extract of $S$. cumini could inhibit DPPH radical. Remarkably, in vitro treatment with 
S. cumini extract significantly induced scavenging activity (IC50 $=$ $9.85 \pm 0.51 \mu \mathrm{g} / \mathrm{ml}$ ), when compared with to ascorbic acid (IC50 $=$ $3.02 \pm 0.09 \mu \mathrm{g} / \mathrm{ml})$ and resveratrol $(8.05 \pm 0.51 \mu \mathrm{g} / \mathrm{ml})-$ used as positive controls. In order to evaluate the possible mechanisms involved in the antioxidant action of $S$. cumini, we next assessed the phenolic and flavonoid contents in the $S$. cumini extract.

The contents of total phenols and flavonoids of ethanol extract of $S$. cumini were $19.69 \pm 0.87$ and $1.21 \pm 0.081 \mathrm{mg} / 100 \mathrm{mg}$, respectively. The results showed the good capacity of the $S$. cumini extract to act against the radical DPPH, which correlates with phenolic compounds contents, such as flavonoids. Therefore, our data confirm and largely extend previous data, which demonstrated that phenolic compounds, such as ferulic acid and catechins are responsible for the antioxidant activity of extracts from the leaves of S. cumini [50]. More recently, Gajera and colleagues demonstrated that the inhibition of DPPH radical scavenging activity was positively correlated with phenol constituents from fruit parts of indigenous $S$. cumini. Moreover, the same authors demonstrated that the seed and kernel of $S$. cumini extracts exhibited higher phenolics-gallic, catechin, ellagic, ferulic acids and quercetin, whereas the pulp evidenced higher with gallic acid and catechin, as $\alpha$-amylase inhibitors [51]. Extending this idea, Chandran and colleagues reported that $S$. mundagam methanol extract showed therapeutic effects on type-2 diabetic complications in rats, which were also correlated with phenolic contents [52]. Next, we assessed whether the treatment with $S$. cumini could induce photoprotection capacity.

The results of Table 1 demonstrate that $S$. cumini extract exhibited a significant photoprotection capacity for a single UV-filter substance, as its SPF was equal to $13 \pm 2.9$. Moreover, the extract also showed a relevant UVA protection (UVA-PF $=5.0$ ) and a critical wavelength value of $385 \mathrm{~nm}$ (Table 1 ). It can be considered as a broad-spectrum filter, according to the Food and Drug Administration, and Colipa [53]. Finally, we determined the UVA/UVB ratio, which provides a good idea of which UV region is better blocked by the substances. The value $(0.550)$ showed that $S$. cumini extract has an important UVA/UVB balance. To our knowledge, this is the first study reporting the photoprotection capacity of the extract of S. cumini leaves. Importantly, natural substances have been considered as potential sunscreen resources because of their absorption in the UV region and their antioxidant activity [54]. Green tea polyphenols; aromatic compounds isolated from lichens; glycosides of esculin and Murraya koenigii leaf are examples of natural substances evaluated for their sunscreen specifications [54].

Table 1: Photoprotection effects of ethanol extract from S. cumini leaves.

\begin{tabular}{|c|c|c|c|c|}
\hline Dry extract/Standard & SPF & UVA - PF & $\boldsymbol{\lambda} \mathbf{c ( n m )}$ & UVA/UVB Ratio \\
\hline S. cumini & $13 \pm 2.9$ & $5 \pm 0.2$ & 385 & 0.55 \\
\hline Resveratrol & $7 \pm 1.7$ & $2 \pm 0.2$ & 362 & 0.46 \\
\hline
\end{tabular}

Note: SPF: sun protection factor; UVAPF: UVA protection factor; $\lambda c$ : critical wavelength. All results were expressed as mean of 27 determinations (3 plates vs. 9 individual readings) for lotion containing 15\% of S. cumini extract, using Cosmetics Europe Reference Sunscreen S2 (SPF $=18$ and UVA - PF $=12)$.

In addition, dried extract of Lippia sericea, Aloe barbadensis and Alpinia speciose have been described in their photoprotective properties. Relevantly, there is strong evidence that DNA-damaging ultraviolet (UV) light induces the accumulation of UV lightabsorbing flavonoids and other phenolic compounds in the dermal tissue of the plant body. This suggests the physiological function, although speculative, in light protection in plants and, of course, in humans [55]. There has been an increasing interest in the use of antioxidants in sunscreens to provide supplemental photoprotective activity. Taken together, we suggest that the photoprotective effects of $S$. cumini extract on sun damage are associated, in part, with antioxidant activity and phenolic compounds, especially flavonoid. For this reason, our result supports the use of antioxidants from $S$. cumini extract as new possibilities for the treatment and prevention of UV-mediated diseases. However, to date, we are not able to confirm whether $S$. cumini leaves show photoprotection effects in vivo. For this reason, future studies are needed to clarify this hypothesis. According to Alam et al. [56], hydroxyl groups of phenolic compounds could inhibit enzymatic activity through hydrogen bond formation with the active site of tyrosinase enzyme.
Some tyrosinase inhibitors act through binding of their hydroxyl groups to the active site of the enzyme, resulting in steric hindrance or conformation change. Moreover, the antioxidant activity may be one of the important mechanisms for tyrosinase inhibition activity. In this set of experiments, we investigated whether the treatment with leaf extracts of $S$. cumini could inhibit tyrosinase activity in vitro. As shown in Table 2, the ethanol extract from S. cumini leaves showed IA\% lower than 50 \% (Table 2). Furthermore, in the quantitative assay, it showed a tyrosinase inhibition capacity markedly lower than kojic acid - used as positive control (Table 2). Although this extract has shown relatively weak tyrosinase inhibition activity, it may act through a different inhibition pathway, which is not based on tyrosinase activity. Therefore, future studies will need to investigate whether $S$. cumini could inhibit this enzyme in epithelial tissue after sun damage, as well as confirm whether or not $S$. cumini directly modulates the tyrosinase activity and/or melanocytes during sun exposition. Human immortalized HaCaT keratinocyte cells closely resemble normal human keratinocytes and therefore represent a valuable in vitro cell model for testing the effects of natural products of cosmetic interest, as well as the cytotoxic effect of natural compounds [57]. 
Table 2: Tyrosinase inhibitory activity of ethanol extracts from S. cumini leaves.

\begin{tabular}{|c|c|c|c|}
\hline Dry extract/Standard & \multicolumn{2}{|c|}{ Tyrosinase inhibitory activity } \\
\hline & IA $60 \mathrm{~min}(\%)$ & IA $120 \mathrm{~min}(\%)$ & IA50 $(\mu \mathrm{g} / \mathrm{ml})$ \\
\hline S. cumini & 48.72 & 46.59 & $219.52^{*}$ \\
\hline Kojic acid & 76.7 & 50.3 & 7.2 \\
\hline
\end{tabular}

Note: The analytical curve was plotted between tyrosinase inhibition activity percentages at each time point and the concentrations of the extract/positive control. Using the equation of the line, the inhibitory activity at $50 \%$ (IA50, $\mu \mathrm{g} / \mathrm{ml}$ ) was calculated. * $<<0.05$ versus positive control group (one-way ANOVA followed by Tukey's test). IA: inhibitory activity.

In this set of experiments, we investigated whether the treatment with ethanol extracts from $S$. cumini leaves could induce cytotoxicity effect in HaCaT keratinocyte cells, through MTT assay. Ethanol extract of $S$. cumini $(125-7.81 \mu \mathrm{g} / \mathrm{ml})$ were not toxic, while the concentrations of 500 and $250 \mu \mathrm{g} / \mathrm{ml}$ revealed modest cytotoxicity when compared to the control and solvent (DMSO) groups after 48 $\mathrm{h}$ incubation (Figure 1). Additionally, brine shrimp lethality assay has been widely documented as a screening method for the assessment of toxicity in mammals and humans $[28,29]$. Therefore, the acute toxic effect of the leaf extract of $S$. cumini was evaluated using an invertebrate in vivo model (A. salina). The LC50 exhibited by this extract was $616.50 \mu \mathrm{g} / \mathrm{ml}$ (Table 3). According to the result, its toxicity to $A$. salina was far below the limit of $1,000 \mu \mathrm{g} / \mathrm{ml}$ reported by Meyer et al. [43]. The mortality of brine shrimp after exposure to $S$. cumini extract was expected to be associated with bioactive compounds and not with starvation. This was confirmed by the absence of brine shrimp death in the negative control group. The brine shrimp toxicity results suggest that the extract does not have high toxicity compared to that of thymol standard (positive control) with LC50 of $42 \mu \mathrm{g} / \mathrm{ml}$. Taken together, as preliminary toxicological data suggest that $S$. cumini is quite safe and did not present any evidence of important cytotoxicity, although additional protocols are necessary to confirm this hypothesis. Moreover, the present data showing that $S$. cumini extract could prevent UV-induced skin damage, including inflammation and cellular toxicity in keratinocytes, support its utilization in cosmetic biopharmaceuticals.

Table 3: Preliminary toxicological effect of S. cumini extract against brine shrimp after 24 hours incubation.

\begin{tabular}{|c|c|}
\hline Dry extract/Standard & $\mathbf{L C}_{50}(\boldsymbol{\mu g} / \mathbf{m l})$ \\
\hline S. cumini & $616.50^{*}$ \\
\hline Thymol & 42 \\
\hline
\end{tabular}

Note: The extracts were tested in triplicate at $1000-10 \mu \mathrm{g} / \mathrm{ml}$. Thymol and $2.5 \%$ DMSO were used as positive and negative controls, respectively. After $24 \mathrm{~h}$, the number of survivors was counted using a binocular microscope, and the percentage of death was calculated. The lethal concentration $50 \%$ (LC50 value) and the standard error were calculated by Probit analysis [44]. *p<0.05 versus positive control group (Student's t-test).

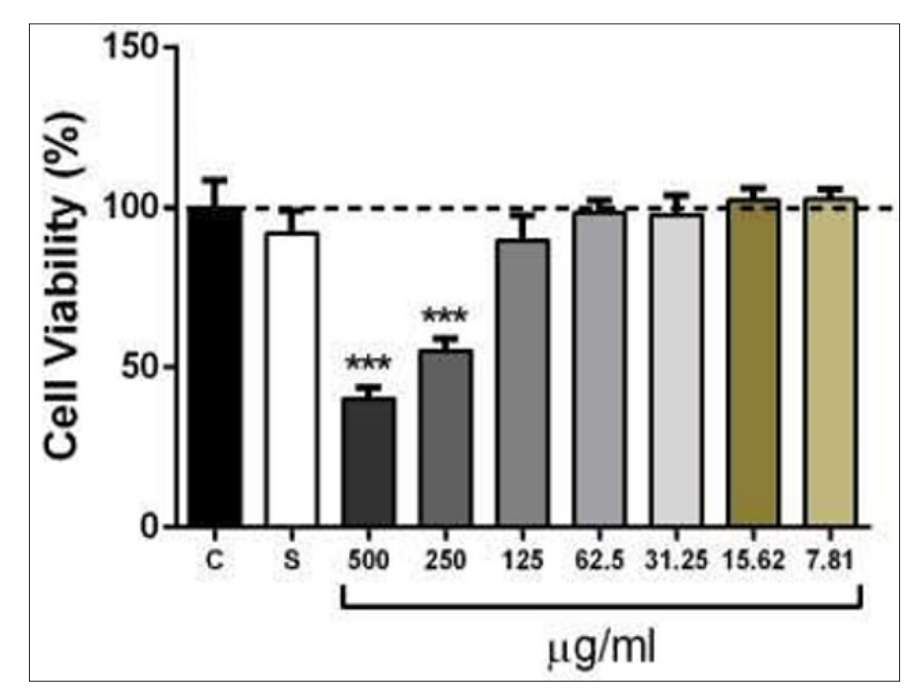

Figure 1: Cytotoxicity effect of ethanol extracts from S. cumini leaves against human immortalized HaCaT keratinocyte cells. Sextuplicate wells were treated with S. cumini extract at concentrations ranging from $500-7.81 \mu \mathrm{g} / \mathrm{ml}$. The plates were incubated at $37^{\circ} \mathrm{C}$ in $5 \% \mathrm{CO}_{2} . \mathrm{IC}_{50}$ value is the concentration of sample required to inhibit $50 \%$ of the cell proliferation and was calculated by plotting the percentage survival vs. the concentrations. ${ }^{* *} \mathrm{p}<0.001$ versus the control group (one-way ANOVA followed by Tukey's test). 


\section{Conclusion}

In summary, data from the present study reveal that ethanol extract of $S$. cumini leaves showed marked phenolic compounds contents, especially flavonoid, and also displayed biological activities, deeming it an ideal cosmetic ingredient, including the DPPH radical scavenging (IC50 $=9.85 \pm 0.51 \mu \mathrm{g} / \mathrm{ml}$ ), tyrosinase inhibition (IA50 value of $219.52 \mu \mathrm{g} / \mathrm{ml}$ ), as well as sun protection factor (13 \pm 2.9 ) activities. Moreover, this extract showed low and moderate cytotoxicity in human keratinocytes and brine shrimp assay. Therefore, the use of this extract, alone or in combination with other active ingredients, may be of interest to the cosmetic industry, because of its anti-aging properties.

\section{Acknowledgement}

This work was supported by grants from the Coordenação de Aperfeiçoamento de Pessoal de Nível Superior (CAPES), the Conselho Nacional de Desenvolvimento Científico e Tecnológico (CNPq), the Fundação de Amparo à Pesquisa do Estado de Minas Gerais (FAPEMIG), and Pró-Reitoria de Pós- Graduação e Pesquisa da Universidade Federal de Juiz de Fora (PROPESQ/UFJF), all of Brazil. R.C.D. is recipient of a research productivity fellowship from the CNPq.

\section{References}

1. Helmstadter A (2008) Syzygium cumini (L.) SKEELS (Myrtaceae) against diabetes--125 years of research. Pharmazie 63(2): 91-101.

2. Chagas VT, França LM, Malik S, Paes AM (2015) Syzygium cumini (L.) skeels: a prominent source of bioactive molecules against cardiometabolic diseases. Front Pharmacol 6: 259.

3. Rodrigues KA, Amorim LV, Dias CN, Moraes DF, Carneiro SM, et al. (2015) Syzygium cumini (L.) Skeels essential oil and its major constituent alphapinene exhibit anti-Leishmania activity through immunomodulation in vitro. J Ethnopharmacol 160: 32-40.

4. Yadav AK, Saraswat S, Sirohi P, Rani M, Srivastava S, et al. (2017) Antimicrobial action of methanolic seed extracts of Syzygium cumini Linn. on Bacillus subtilis. AMB Express 7(1): 196.

5. Dos Santos MM, Prestes AS, de Macedo GT, Ecker A, Barcelos RP (2018) Syzygium cumini leaf extract inhibits LDL oxidation but does not protect the liproprotein from glycation. J Ethnopharmacol 210: 69-79.

6. Perera PRD (2017) Antidiabetic Compounds in Syzygium cumini Decoction and Ready to Serve Herbal Drink. Evid Based Complement Alternat Med 1083589.

7. Pereira JV, Freires IA, Castilho AR, da Cunha MG, Alves Hda S, et al (2016) Antifungal potential of Sideroxylon obtusifolium and Syzygium cumini and their mode of action against Candida albicans. Pharm Biol 54 (10): 2312-2319.

8. Chanudom L, Tangpong J (2015) Anti-Inflammation Property of Syzygium cumini (L.) Skeels on Indomethacin-Induced Acute Gastric Ulceration. Gastroenterol Res Pract 343642.

9. Ribeiro RM, Vicente Férrer Pinheiro Neto, Kllysmann Santos Ribeiro, Denilson Amorim Vieira, Iracelle Carvalho Abreu, et al. (2014) Antihypertensive Effect of Syzygium cumini in Spontaneously Hypertensive Rats. Evid Based Complement Alternat Med 605452.

10. Do Carmo Brito BN (2017) Anthocyanins of Jambolao (Syzygium cumini): Extraction and pH-Dependent Color Changes. J Food Sci 82 (10): 22862290.
11. Syama HP, Arya AD, Dhanya R, Nisha P, Sundaresan A, et al. (2017) Quantification of phenolics in Syzygium cumini seed and their modulatory role on tertiary butyl-hydrogen peroxide-induced oxidative stress in H9c2 cell lines and key enzymes in cardioprotection. J Food Sci Technol 54(7): 2115-2125.

12. Sutariya B, Taneja N, Saraf M (2017) Betulinic acid, isolated from the leaves of Syzygium cumini (L.) Skeels, ameliorates the proteinuria in experimental membranous nephropathy through regulating Nrf2/NFkappaB pathways. Chem Biol Interact 274: 124-137.

13. Priya SH (2017) Antioxidant activity, phenolic-flavonoid content and high-performance liquid chromatography profiling of three different variants of Syzygium cumini seeds: A comparative study. J Intercult Ethnopharmacol 6(1): 107-114.

14. Sanches JR, França LM, Chagas VT, Gaspar RS, Dos Santos KA, et al. (2016) Polyphenol-Rich Extract of Syzygium cumini Leaf Dually Improves Peripheral Insulin Sensitivity and Pancreatic Islet Function in Monosodium L-Glutamate-Induced Obese Rats. Front Pharmacol 7: 48.

15. De Bona KS, Bonfanti G, Bitencourt PE, da Silva TP, Borges RM, et al. (2016) Protective effect of gallic acid and Syzygium cumini extract against oxidative stress-induced cellular injury in human lymphocytes. Drug Chem Toxicol 39(3): 256-263.

16. Gopu V, Kothandapani S, Shetty PH. (2015) Quorum quenching activity of Syzygium cumini (L.) Skeels and it anthocyanin malvidin against Klebsiella pneumoniae. Microb Pathog 79: 61-69.

17. MS, KB, MB, SJ, SA, et al. (2017) Obtaining titanium dioxide nanoparticles with spherical shape and antimicrobial properties using M. citrifolia leaves extract by hydrothermal method. J Photochem Photobiol B 171: 117-124.

18. Mejia Giraldo JC (2016) Photoprotective Potential of Baccharis antioquensis (Asteraceae) as Natural Sunscreen. Photochem Photobiol 92(5): 742-752.

19. Biswas R, Mukherjee PK, Kar A, Bahadur S, Harwansh RK, et al. (2016) Evaluation of Ubtan - A traditional indian skin care formulation. J Ethnopharmacol 192: 283-291.

20. Fernandes AS, Mazzei JL, Oliveira CG, Evangelista H, Marques MR, et al. (2017) Protection against UV-induced toxicity and lack of mutagenicity of Antarctic Sanionia uncinata. Toxicology 376: 126-136.

21. Creis E, Delage L, Charton S, Goulitquer S, Leblanc C, et al. (2015) Constitutive or Inducible Protective Mechanisms against UV-B Radiation in the Brown Alga Fucus vesiculosus? A Study of Gene Expression and Phlorotannin Content Responses. PLoS One 10(6): e0128003.

22. Bulla MK, Hernandes L, Baesso ML, Nogueira AC, Bento AC, et al. (2015) Evaluation of Photoprotective Potential and Percutaneous Penetration by Photoacoustic Spectroscopy of the Schinus terebinthifolius Raddi Extract. Photochem Photobiol 91(3): 558-566.

23. Pereira RF, Bartolo PJ (2016) Traditional Therapies for Skin Wound Healing. Adv Wound Care (New Rochelle) 5(5): 208-229.

24. Korac RR, Khambholja KM (2011) Potential of herbs in skin protection from ultraviolet radiation. Pharmacogn Rev 5(10): 164-173.

25. Huang CY, Lin YT, Kuo HC, Chiou WF, Lee MH (2017) Compounds isolated from Eriobotrya deflexa leaves protect against ultraviolet radiation B-induced photoaging in human fibroblasts. J Photochem Photobiol B 175: 244-253.

26. Moison RM, Rijnkels JM, Podda E, Righele F, Tomasello F, et al. (2003) Topically applied vitamin $\mathrm{C}$ and cysteine derivatives protect against UVAinduced photodegradation of suprofen in ex vivo pigskin. Photochem Photobiol 77(4): 343-348.

27. Perricone NV, Di Nardo JC (1996) Photoprotective and antiinflammatory effects of topical glycolic acid. Dermatol Surg 22(5): 435-437. 
28. Akhalwaya S, van Vuuren S, Patel M (2018) An in vitro investigation of indigenous South African medicinal plantsused to treat oral infections. J Ethnopharmacol 210: 359-371.

29. Ogbole 00, Peter A Segun, Adekunle J Adeniji (2017) In vitro cytotoxic activity of medicinal plants from Nigeria ethnomedicine on Rhabdomyosarcoma cancer cell line and HPLC analysis of active extracts. BMC Complement Altern Med 17(1): 494.

30. Jamil S, Khan RA, Afroz S, Ahmed S (2016) Phytochemistry, Brine shrimp lethality and mice acute oral toxicity studies on seed extracts of Vernonia anthelmintica. Pak J Pharm Sci 29(6): 2053-2057.

31. Saleh EIMM (2016) Pharmacological effects of the phytochemicals of Anethum sowa L. root extracts. BMC Complement Altern Med 16(1): 464.

32. Du FY, Xin Li, Xiao Ming Li, LiWei Zhu (2017) Indolediketopiperazine Alkaloids from Eurotium cristatum EN-220, an Endophytic Fungus Isolated from the Marine Alga Sargassum thunbergii. Mar Drugs 15(2).

33. Seo MD, Kang TJ, Lee CH, Lee AY, Noh M, (2012) HaCaT Keratinocytes and Primary Epidermal Keratinocytes Have Different Transcriptional Profiles of Cornified Envelope-Associated Genes to $\mathrm{T}$ Helper Cell Cytokines. Biomol Ther (Seoul) 20(2): 171-176.

34. Poumay Y, Coquette A (2007) Modelling the human epidermis in vitro: tools for basic and applied research. Arch Dermatol Res 298(8): 361369.

35. Matos FJA (2009) Introdução à fitoquímica experimental.

36. Bigagli E, Cinci L, D Ambrosio M, Luceri C (2017) Pharmacological activities of an eye drop containing Matricaria chamomilla and Euphrasia officinalis extracts in UVB-induced oxidative stress and inflammation of human corneal cells. J Photochem Photobiol B 173: 618-625.

37. Quettier Deleu C, (2000) Phenolic compounds and antioxidant activities of buckwheat (Fagopyrum esculentum Moench) hulls and flour. J Ethnopharmacol 72 (1-2): 35-42.

38. Sreejayan N, Rao MN (1996) Free radical scavenging activity of curcuminoids. Arzneimittelforschung 46(2): 169-171.

39. Polonini HC, Lima LL, Gonçalves KM, do Carmo AM, da Silva AD, et al. (2013) Photoprotective activity of resveratrol analogues. Bioorg Med Chem 21(4): 964-968.

40. Martins FJ, Caneschi CA, Vieira JL, Barbosa W, Raposo NR (2016) Antioxidant activity and potential photoprotective from amazon native flora extracts. J Photochem Photobiol B 161: 34-39.

41. Adhikari A (2008) Screening of Nepalese crude drugs traditionally used to treat hyperpigmentation: in vitro tyrosinase inhibition. Int J Cosmet Sci 30(5): 353-360.

42. Dos Santos Filho EX, da Silva ACG, de Ávila RI, Batista AC, Marreto RN, et al. (2018) Chemopreventive effects of FITOPROT against 5-fluorouracilinduced toxicity in HaCaT cells. Life Sci 193: 300-308.

\section{ISSN: 2574-1241}

DOI: 10.26717/BJSTR.2019.13.002447

Rafael C Dutra. Biomed J Sci \& Tech Res

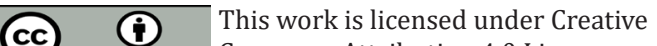
Commons Attribution 4.0 License

Submission Link: https://biomedres.us/submit-manuscript.php
43. Meyer BN, Ferrigni NR, Putnam JE, Jacobsen LB, Nichols DE, et al. (1982) Brine shrimp: a convenient general bioassay for active plant constituents. Planta Med 45(5): 31-34.

44. Archer TE (1985) Acute oral toxicity as LD50 (mg/kg) of propargyl alcohol to male and female rats. J Environ Sci Health B 20(5): 593-596.

45. Ayyanar M, Subash Babu P (2012) Syzygium cumini (L.) Skeels: a review of its phytochemical constituents and traditional uses. Asian Pac J Trop Biomed 2(3): 240-246.

46. Ross JA, Kasum CM (2002) Dietary flavonoids: bioavailability, metabolic effects, and safety. Annu Rev Nutr 22: 19-34.

47. Dzialo M, Mierziak J, Korzun U, Preisner M, Szopa J, et al. (2016) The Potential of Plant Phenolics in Prevention and Therapy of Skin Disorders. Int J Mol Sci 17(2): 160.

48. Li S, Tan HY, Wang N, Zhang ZJ, Lao L, et al. (2015) The Role of Oxidative Stress and Antioxidants in Liver Diseases. Int J Mol Sci 16(11): $26087-$ 26124.

49. Shenoy C (2009) Wound healing activity of Hyptis suaveolens (L.) Poit (Lamiaceae) International Journal of PharmTech Research 1(3): 737744 .

50. Ruan ZP, Zhang LL, Lin YM (2008) Evaluation of the antioxidant activity of Syzygium cumini leaves. Molecules 13(10): 2545-2556.

51. Gajera HP, Gevariya SN, Hirpara DG, Patel SV, Golakiya BA (2017) Antidiabetic and antioxidant functionality associated with phenolic constituents from fruit parts of indigenous black jamun (Syzygium cumini L.) landraces. J Food Sci Technol 54(10): 3180-3191.

52. Chandran R, Blassan P George, Heidi Abrahamse, Thangaraj Parimelazhagan (2017) Therapeutic effects of Syzygium mundagam bark methanol extract on type- 2 diabetic complications in rats. Biomed Pharmacother 95: 167-174.

53. Macmillan R, Lisansky SG (1998) Global cosmetic regulatory harmonization: An impetus to the development of export markets : a COLIPA-UNIPRO initiative \& a prelude to Cosmoprof, Florence, Italy 2223.

54. Ebrahimzadeh, MA, Enayatifard R, Khalili M, Ghaffarloo M, Saeedi M, et al. (2014) Correlation between Sun Protection Factor and Antioxidant Activity, Phenol and Flavonoid Contents of some Medicinal Plants. Iran J Pharm Res 13(3): 1041-1047.

55. Kucera B, Gerhard Leubner Metzger, Eckard Wellmann (2003) Distinct ultraviolet-signaling pathways in bean leaves. DNA damage is associated with beta-1,3-glucanase gene induction, but not with flavonoid formation. Plant Physiol 133(4): 1445-1452.

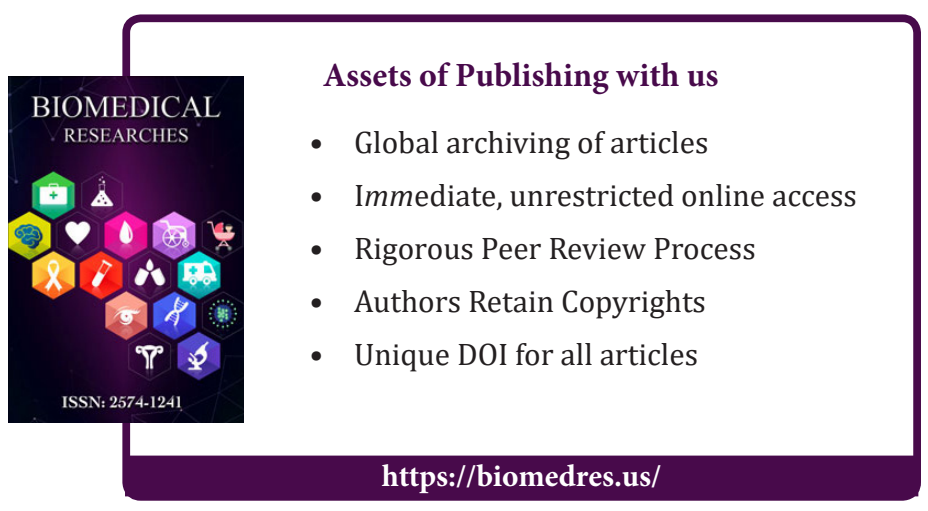

Cite this article: Rebeca M L, Hudson C P, Marcos AF B, Francisco J R, Rafael C D, Nádia RB Rap. In vitro Assessment of Anti-aging Properties 